\title{
Marketing mechanisms in the activity of the regional innovation ecosystem
}

\author{
Darya Lanskaya*, Vladimir Ermolenko, Irina Mironova, Marina Todika, and Anastasia Yakovlenko \\ Kuban State University, Krasnodar, Russia
}

\begin{abstract}
The paper examines marketing problems in the activity of the innovative ecosystem of the region, the main directions of world trends in the field of innovation. The study is aimed at adapting traditional marketing methods to the specifics of the innovation market in the context of conflicting global competition in order to achieve a stable position of innovative subjects in the market of innovations. The factors that determine the life cycle of innovative ecosystems and the reasons for the very modest results of their activities are identified. The evolution of the content of the marketing mix is considered and the future of innovation is associated with marketing transformations towards customer satisfaction and retention in the innovation market. Marketing in environmental systems has a multi-circuit and multi-layer configuration structure, focused on all the special actors of the innovation ecosystem.
\end{abstract}

\section{Introduction}

An important pole of the new quality of growth and development is innovation as a direction for the formation of sustainable competitive advantages, which ensures an increase in the value of gross domestic product. The main global trends in the field of innovation can be defined by a number of main directions:

- inertial and opportunistic behavior of the subjects of the innovation market, especially the consumers;

- strengthening the role of the state as a customer of innovation and an investor;

- availability of government programs and projects in the established areas of development;

- availability of budget financing in the country and regions of innovation activity;

- democratization of the innovation process based on cooperation, integration and pooling of capitals especially non-material ones;

- slowness of the corporate investment and venture investment system;

- inhibiting effect of the existing system of intellectual property protection;

- the tax system has not acquired a stimulating effect on all participants in the innovation process;

- attracting young people with a special energy of renewal and social activity;

\footnotetext{
* Corresponding author: Lanskayadv@yandex.ru
} 
- sluggish and delay pace of the formation of a functionally complete and systemic innovation infrastructure in the regions in comparison with the growing demands of the regional community for development;

- formation of a special social national stratum of creators - devotees of innovative development, able to apply their intellect and energy.

Researchers are focused on innovation ecosystems. The evolutionary approach in relation to the innovation ecosystem in the part that studies the scientific problem of the emergence and development of ecosystems in the economy has cognitive and applied potential. The idea of national innovation systems has been extended to regional, corporate and local levels. The actors of such a system are innovative companies, universities and research institutes, innovation brokers, etc. At the same time, the bionic approach to the creation and development of innovative ecosystems is present in most studies.

The study is aimed at adapting traditional marketing methods to the specifics of the innovation market in the context of conflicting global competition in order to achieve a stable position of innovation activity in the innovation market.

\section{Literature review of major sources}

The greatest contribution to solving the problems of innovative development is made by S.D. Bordunov [1], O.G. Golichenko [2], N.I. Ivanova [3], V.E. Dementyev [4], A.I. Dobrynin [5], I.V. Nikitenko [6], Yu.P. Anisimov [7] et al.

The entrepreneurial ecosystem was viewed as a complex system with the properties of self-organization, emergentism, co-evolution, and adaptability. M. Peltoniemi defines it as a dynamic structure, within which the processes of cooperation and competition are present simultaneously. [8]. J.F. Moore researched networks of entrepreneurial communities and was close to the idea of value chains with a high degree of self-organization and decentralized decision-making [9]. G.B. Kleiner considers both entrepreneurial and innovation ecosystems as environmental, within which favorable conditions are formed for giving innovations the finished qualities of a product for subsequent entry into the market of innovations. Environmental systems constitute a semi-structured space in which conditions and free movement of flows of tangible and intangible capital, talented people and venture capital operate [10]. The elements of such a system are environments in the form of various professional communities, as well as institutions and informal institutions, from whose cooperative activities clusters of an informal nature grow. The idea of innovative ecosystems is fueled by the evolving concept of "open innovation", as well as the ideas of a prticipation and co-creation (combining efforts to create, develop and market innovations, as well as intellectual human capital) [11]. The theory of innovative environments was interpreted in the philosophical works of V.E. Lepsky [12].

In our opinion, an innovation network is a network of innovative organizations in an entrepreneurial network, a type of inter-firm network, the main distinguishing feature of which is the presence of subsystems for the development of innovations and their commercialization, as well as scientific organizations and venture investors. Innovative networks are the most mobile form of innovative business.

An innovation ecosystem is a formal and informal association (community) of bearers of intellectual human capital who have sufficiently strong professional and cooperative ties for the exchange, dissemination and distribution of knowledge and financial resources, as well as their transformation into goods, services and business processes. The goal of the network community is to organize active interaction between the participants in the innovation process, during which, due to the complementarity of resources and competencies, project teams are formed to carry out innovation and investment projects. In every area of innovation, developers and innovators, as well as venture capitalists, 
practically "observe" or "see" each other by monitoring the innovation market. Such networks develop due to the property of self-organization and the manifestation of synergy in the process of introducing innovations to the innovation market. And they can disappear, creating a new network in the future for a specific project or idea. The network is a temporary formation (community). However, there are stable communities among them. Their life cycle is determined by a number of factors:

- reserve of scientific results of fundamental and applied science;

- emergence of breakthrough ideas;

- a stream of innovative and investment projects;

- needs of enterprises or growing demand;

- the return on implemented innovations;

- change of technological structures;

- mass youth training in science-intensive areas;

- social attitude to the need to conduct productive innovative activities;

- support of innovative activities from the state and motivation of ongoing projects, etc.

Thus, the objects of attention in the region are the environments with developed cooperative ties and relations, due to the accumulation of intellectual human capital and talents and the development of institutions that contribute to the integration process. The main players taking advantage of the environmental systems are small innovative companies, deprived of necessary resources and in dire need of them. They have specific characteristics, great flexibility, low overhead costs. Their advantages are the continuation of market freedom, capital mobility and management resources of the innovation ecosystem [13].

\section{Evolution of the marketing complex}

Innovative ecosystems of dozens of regions demonstrate modest results of their activities on a number of indicators. The main reasons are the following:

- the model and mechanisms of its activity do not reflect the market orientation, but are a continuation of the research work;

- the market nature of the work did not find its support either in the content of the activity or in the construction of its organizational design;

- the regulations of infrastructure units and officials are not saturated with marketing tools for organizing innovative activity in the innovation market;

- the personnel of the infrastructure of the innovation system does not have developed competencies for professional activities in the innovation market and, in fact, acts also as active researchers within the scientific subsystem

- criteria and indicators of infrastructure performance do not reflect the specifics and market content of personnel work in the innovation market;

- Controlling tools have not found application in analytical activities in marketing.

The fundamental problem of modern marketing in the innovation sphere is the underdevelopment of the market philosophy of the innovation ecosystem's activity [12].

Adherence to old approaches and the imposition of innovative activities on scientific workers are noted. Substantively, scientific and innovative activities are different areas in terms of working methods. Scientific is, first of all, search, fundamental and applied creative activity related to the generation of new knowledge and their transformation into innovations. And innovative activity is the behavior in the innovation market on behalf of the author (owner) of the innovation.

Hooley, Greenley, Cadogan, and Fahy explore how marketing resources can help create the competitive advantage of an innovative enterprise [14]. The results of their research show marketing resources and conditions for obtaining financial results, taking care of the 
satisfaction and loyalty of consumers of innovations, as well as improving the quality of activities of the subjects of the innovation market. Rust, Ambler, Carpenter, Kumar, and Srivastava show how marketing costs increase the value of an innovative product and the market value of an innovative business [15].

Marketing begins with a study of the spectrum of needs of the subjects in the innovation market. The results of market research, combined with an assessment of the macro and micro environment, form the basis for assessing the company's position in the market and confirm the mission and specific operational objectives. Consequently, marketers use these results to set marketing goals and develop marketing strategies, resulting in marketing tools being implemented. The combination of such tools allows marketers to achieve the optimal marketing mix, providing a synergistic effect for the infrastructure of the innovation ecosystem. Saludin, Solomon define a marketing mix as a set of controlled marketing variables that the infrastructure combines with a specific small business to trigger the desired response in the target market for innovation [16,17].

According to Ginevicius, Podvezko, and Givevicius, the marketing mix includes all types of activities through which the infrastructure can influence the demand for its innovations. Greater customer satisfaction and gaining an advantage in a competitive environment is achieved through the appropriate marketing mix 7P [18]

The work on the universal concept of the marketing mix has been going on for many years. Since the 1980s, a number of researchers have proposed elements in the marketing mix: people; participants, physical evidences and a process; political power and the formation of public opinion; personnel, physical equipment and process control; 15P concept, i.e. product / service, price, promotion, place, people, politics, public relations, research, separation, prioritization, position; profit, plan, performance, positive realizations; maintaining existing customers is important to be proactive, based on a separate marketing mix for customer retention: complementary products supporting promotions, relationships with sellers, specialized distribution, post-purchase communication; as well as attracting new ones; personalization, personnel (members), physical assets and processes; the desires and needs of consumers, the cost of satisfaction, ease of purchase and communication $[19,20]$. Kotler noted that external and uncontrollable environmental factors are key elements of marketing strategy programs [19].

In the 4P mix, two factors are essential: services and personnel. Personalization should be the backbone of the marketing mix management trajectory. The marketing mix has shifted towards accessibility, awareness and acceptability.

Customers play an important role. The criteria for the location of customers are: value, vitality, variety, volume, dignity. One of the most important factors to consider is customers or target market and their behavior to match how each aspect of the marketing mix is viewed by organizations. Accordingly, they proposed the 80 formula and are composed of: occupier, object, event, purpose, output, organization, operations and opposition. The emphasis will be placed only on the first four of the eight "O". These include: object, purpose, organization and action. Hence, it is known and recognized as $4 \mathrm{O}$ [21]

So, in the literature, many useful compositions have been proposed, containing groups of factors that affect the decision-making processes of entrepreneurs and consumers. The described formulas of the marketing mix contain from three to eight elements. One of the most important aspects is that the proportions in the marketing mix can change and differ from product to product and from client to customer. The marketing mix management paradigm has dominated the thinking, research, and practice of mix marketing. The marketing mix has had a particular impact on the development of marketing theory and practice. 


\section{Features of marketing in environmental systems}

In the innovation ecosystem, the marketing function has more influence. In the stream of scientific publications on marketing, the importance of marketing in environmental systems and the mechanisms for transferring market capital to innovations from them to small innovative companies are insufficiently considered. How does knowledge of current market conditions and consumer need in the environmental innovation ecosystem positively affect the performance of small innovative companies? One aspect of marketing, advertising, was found to have a key impact on their bottom line. Simpson et al. examined the driving forces of marketing efforts, such as the presence of a marketing department and marketing activities at the level of the directorate of the region's innovation ecosystem [22]. A small innovative company lacks the resources either for marketing or for direct competition in the innovation market. This marketing function is assumed (as well as others) by the infrastructure of the innovation ecosystem. Then the infrastructure marketing function has a positive effect on the success of a small innovative company [13].

Small firms operate at the entrance to the innovation market through highly informal, unstructured, reactive mechanisms, while others over time develop a proactive and skillful approach in which innovation and opportunity identification give them a competitive advantage.

A widely cited marketing activity for companies is networking. Traditional economic structures favor firm size. However, an innovative economy is defined by relationships, networks and information.

Two theories provide a conceptual framework for explaining differences in the impact of marketing function: institutional theory and contingency theory. Institutional theory argues that organizational structure and design are inextricably linked to social media and are shaped under the pressure of conformity and legitimacy. Firm structure does not necessarily reflect efficiency, but legitimacy. Thus, the impact of a firm function, such as marketing, is a function of conformity / legality pressures. Contingency theory alternatively states that organizational structure and design are a function of external factors. Firms must adapt to their external environment. Firm structure does not necessarily reflect efficiency, but legitimacy.

The status and role of marketing in the innovation ecosystem is less significant than in consumer markets. At the same time, the formalization of marketing in the innovation ecosystem is high and its activity is regulated by local regulations. Therefore, it works in large organizations in the field of standards and regulations.

Marketing influence is more important to a differentiation strategy than to the leadership strategy in costs. For a company to adhere to a differentiation strategy, it must identify customer needs and develop products that meet those needs. Identifying these needs is one of the core competencies of the marketing department and is likely to lead to greater marketing influence within the firm.

As Stevenson and Gumpert noted, entrepreneurial firms tend to be flat organizations with informal networks of employees and functions. Entrepreneurial organizations tend to have evolving governance structures and more abstractly define leadership roles. Nonentrepreneurial firms are called administratively oriented and are organizations with clearly defined powers and structures.

The strategy of marketing mix can be determined by three factors [19]. The three Cs define and create the marketing mix strategy: customers, competitors, corporation. The $4 \mathrm{P}$ marketing mix is overly focused on the domestic market. The four Cs express the foreign orientation of the marketing mix: customers, competitors, opportunities, company. Thus, the traditional marketing mix is clearly offensive, as the strategies associated with 4Ps tend to be function-oriented and result-oriented. Well-managed organizations must shift their 
focus on value-added customer relationship management in order to retain and grow their customer base. Four information-intensive strategies create "new components" of the marketing mix: communication, customization, collaboration, clairvoyance.

Marketing management is clearly leaning towards relationship marketing as a forwardlooking marketing paradigm. Relationship marketing refers to elements of the marketing mix - management identified by the marketing relationship trilogy: relationships, new relationship marketing, networks. The development of the marketing mix over the past 50 years requires a new flexible platform.

The analysis of existing concepts influencing the decisions of the actors operating in the market leads to the creation of integrated solutions designed to create a symbiotic space. A space that integrates differences in mechanisms that stimulate the activity of clients and decision-makers. They form a single whole. Marketing tools need to be transformed to be effective. Instead of being guided by decision makers, it is necessary to redefine relationships with customers using 4 ps tools as a way to emphasize customer value on an individual basis. In economically developed countries, personalized offerings are expected to create value for the customer in a unique and personalized way.

Influenced by the development of digital technologies, ever-increasing competition, globalization and the growing interdependence of different parts of the world, the perception of marketing and its activities has also changed in the market environment. In today's market environment with different target markets for innovation, the goal of marketing is to retain loyal customers by meeting their individual needs. Customer service generates more revenue. Ateba, Maredza, Ohei, Deka, and Schutte point out that mix marketing is an important tool for satisfying and retaining customers in the innovation market [23].

The mission of environmental innovation ecosystems is to create a wide field of opportunities for the rapid movement of innovation flows, financial, information resources and carriers of intellectual human capital. Therefore, marketing in the environment system has a multi-circuit and multilayer configuration structure, focused on all the special actors of the innovation ecosystem.

\section{Conclusion}

The main global trends in the field of innovation can be determined by key areas that determine the development of innovation ecosystems. The evolutionary approach as applied to the innovation ecosystem studies the scientific problem of the emergence and development of ecosystems in the economy. Much research has focused on the bionic approach. Innovative systems are rapidly evolving and, in terms of the content of their activities, are classified as environmental ones. The main players taking advantage of the environmental systems are small innovative companies, deprived of necessary resources and in dire need of them. The advantages of small innovative companies are the continuation of market freedom, capital mobility and management resources of the innovation ecosystem. Among the reasons for the low performance, the fundamental problem of modern marketing in the innovation sphere is highlighted - the underdevelopment of the market philosophy of the innovation ecosystem. One of the most important aspects is the proportions in the marketing mix, which can change and differ from product to product and from customer to customer. Marketing management is clearly leaning towards relationship marketing as a marketing prospect paradigm. Marketing in the environment system has a multi-circuit and multi-layer configuration structure, focused on all the special actors of the innovation ecosystem. 


\section{References}

1. S.D. Bodrunov, Formation of a strategy for the reindustrialization of Russia (SPb.: INIR, 2015).

2. O.G. Golichenko, A.K. Kazantsev, D.A. Rubvalter Public-private partnership in the scientific and innovation sphere (Moscow: INFRA, 2009).

3. N.I. Ivanova National innovation systems, (Moscow: Science, 2002).

4. Innovative orientation of Russian economic institutions, (Book House "Librokom" 2009)

5. A.I. Dobrynina, E. S. Ivleva, Methods and mechanisms for managing the development of innovative activities: ( Publishing house of the St. Petersburg University of Management and Economics, 2015).

6. I. V. Nikitenko Management of innovative development of high-tech corporations in Russia: monograph, (Rusayns Publishing House, 2015).

7. Yu. P. Anisimov, Yu. V. Zhuravlev, S.V. Sviridova, I. V. Usacheva, Management of innovation activity (Voronezh State Technical University, 2011).

8. M. Peltoniemi, E. Vuori Business ecosystem as the new approach to complex adaptive business environments Retrieved, http://www.iwoce.org/definitionsof-ecosystems.pdf

9. J.F.Moore The death of competition: leadership and strategy in the age of business ecosystems (Harper Business, 1997).

10. G.B .Kleiner, R.M. Kachalov, N.B. Nagrudnaya Synthesis of cluster strategy based on system integration theory Retrieved, http://www.kleiner.ru/arpab/klaster.html

11. G. Chesbro, Open Business Models. IP management ( Pokoenie, 2008).

12. V.E. Lepsky Reflexive-active environments of innovative development, (Kogito-Centre 2010).

13. D.V. Lanskaya, K.V. Getmantsev, V.V. Ermolenko, The Future of the Global (ISC) (2018).

14. G. J. Hooley, G.E. Greenley, J.W. Cadogan, J. Fahy, Journal of Business Research, 58 (1), 18 (2005).

15. R. T. Rust, T. Ambler, G. S. Carpenter, V. Kumar, R. K. Srivastava Journal of Marketing, 68 (4), 76 (2004).

16. M. N. Saludin, A. L.Poh, C. Z. Syin, I. L. J. Jiang, A.Tan, X.W. Wong Journal of Productivity Measurement. (2007).

17. M. R. Solomon, Pearson Prentice Hall (2009).

18. R. Ginevičius, V. Podvezko, A. Givevicius, Journal of Business Economics and Management, 14 (1), 200 (2013).

19. P. Kotler, K. L. Keller A framework for marketing management (New Jersey: Prentice Hall, 2012).

20. F.E. Webster Marketing Management, 11 (1), 18(2003).

21. Ch. Lovelock Marketing services, (Moscow: Williams 2005)

22. M. Simpson, N. Taylor, Journal of Small Business and Enterprise Development, 9 (4), 370 (2002)

23. B. B. Ateba, A. Maredza, K. Ohei, P.Deka, D. Schutte, Banks and Bank Systems, 10 (1), 83 (2015) 